\title{
ANALISIS PENYUSUNAN DOKUMEN DESAIN UNTUK PERANCANGAN INTERIOR RUANG VIRTUAL SALON DAN SPA
}

\author{
Mitsalina Ghoisanie*1, Eddy Prianto ${ }^{2}$ \\ Departemen Arsitektur Universitas Diponegoro \\ *Correspondence author: mitsaghoisanie@undip.ac.id, Bekasi, Indonesia
}

\begin{abstract}
Abstrak. Setiap ruangan interior harus dirancang dan diatur sedemikian rupa demi mendukung kegiatan di dalamnya. Pada dasarnya desain interior itu bertujuan agar pengguna di dalam ruangan tersebut dapat merasa nyaman dan dapat menggunakan ruangan tersebut dengan efektif. Maka dari itu, untuk mewujudkan desain interior ruangan yang baik seorang desainer interior harus memahami fungsi dan kegunaan ruang serta kebutuhan para pengguna sebelum merancang, mulai dari mengatur warna, material, peletakan furnitur dan lain - lain. Untuk itu, tahapan - tahapan yang dilakukan untuk pra-perancangan hingga pasca-perancangan interior harus disusun ke dalam dokumen desain, dengan tujuan untuk membuat proses perancangan lebih terstruktur dan jelas. Dalam penelitian ini, contoh untuk salah satu studi kasus perancangan adalah salon dan spa dalam bentuk ruang virtual (tidak nyata). Metode yang digunakan adalah metode studi literatur, mulai dari perancangan interior yang berupa pengumpulan dan analisis data, penyusunan konsep dan programming ruang, pembuatan gambar kerja pendukung, kemudian hasil dari perancangan akan dimasukkan ke dalam dokumen desain. Adapun proses pembuatan dokumen sekaligus menjadi isi dari dokumen terdiri dari beberapa tahapan, yaitu [1] Mengetahui Sistem Manajemen Keselamatan, Kesehatan Kerja dan Lingkungan serta penerapannya dalam desain interior, [2] Pemahaman Tahapan Studi Kelayakan Data, [3] Tahapan Pra-Rancangan, [4] Membuat Rancangan, [5] Mengerti dan memahami dokumen pelaksanaan, [6] Mengerti tahapan dan proses pengawasan berkala, [7] Memahami cara membuat laporan pekerjaan.
\end{abstract}

Kata Kunci: Dokumen Desain, Interior, Salon, Spa.

\begin{abstract}
Interior room must be designed and arranged in such a way as to support the activities in it. Basically, the interior design aims to make the user in the room feel comfortable and be able to use the room effectively. Therefore, to create a good interior design, an interior designer must understand the functions and uses of space and the needs of the user before designing, starting from arranging colors, materials, placing furniture and so on. For this reason, steps are made for the pre-design to post-interior design must be compiled in a design document, with the aim of making the design process more structured and clear. In this study, an example for one of the design case studies is a salon and spa in the form of a virtual space. The research method used is a literature review, started from interior designing in the form of data collection and analysis, drafting and programming of space, making supporting work drawings, then the results of the design will be entered into the design document. The document-making process as well as the contents of the document consists of several stages, namely [1] Knowing the Safety, Occupational Health and Environment Management System and its application in interior design, [2] Understanding the Stages of Data Feasibility Studies, [3] Pre-Design Stages, [4] Designing, [5] Understanding and understanding implementation documents, [6] Understanding the stages and processes of periodic supervision, [7] Understanding how to make work reports.
\end{abstract}

Keywords: Design Document, Interior, Salon, Spa. 


\section{Pendahuluan}

Setiap kegiatan atau pekerjaan yang dilakukan seperti di rumah, sekolah, tempat kerja, dan tempat yang lain pasti membutuhkan sarana, prasarana serta lingkungan yang mendukung agar manusia dapat melakukan kegiatan atau pekerjaan tersebut dengan maksimal, itu berlaku di dalam maupun luar ruangan. Di setiap ruangan sendiri harus di desain dan diatur sedemikian rupa demi mendukung kegiatan di dalamnya, pada hal ini adalah desain ruangan dalam. Karena pada dasarnya desain interior itu bertujuan agar pengguna di dalam ruangan tersebut dapat merasa nyaman dan menggunakan ruangan tersebut dengan efektif, Dodsworth dalam (Nugraha 2017).

Salon dan spa dikenal menjadi salah satu cara bagi masyarakat untuk memanjakan diri dengan berbagai pelayanan yang disediakan, seperti perawatan rambut dan kulit hingga perawatan tubuh secara menyeluruh. Salon kecantikan adalah tempat untuk merawat kecantikan, sementara spa lebih mengarah kepada tempat untuk merawat kebugaran tubuh. Melihat bahwa adalah bagian dari treatment untuk merawat dan merelaksasi diri, maka desain interior salon dan spa menjadi penting untuk diperhatikan demi membentuk suasana yang sesuai bagi para pengguna sekaligus untuk memenuhi tujuan dari salon dan spa.

Penelitian penyusunan dokumen desain interior dalam mendesain ruang interior salon dan spa menjadi penting demi tercapainya kegunaan dan fungsi ruang yang maksimal dan juga memenuhi kebutuhan para penggunanya dengan baik. Tujuan yang ingin dicapai dalam membuat penelitian ini adalah untuk mengetahui tahapan perencanaan interior suatu ruangan dan bagaimana proses penyusunan dokumen desain untuk perancangan interior, selain itu penelitian ini bisa digunakan sebagai refrensi untuk penyusunan dokumen serupa di masa mendatang, terutama dalam project salon dan spa.

\section{Metode}

\section{Metode Pengumpulan Data}

Dalam penelitian ini menggunakan pendekatan atau jenis penelitian Studi Kepustakaan (Library Research). Penelitian Kepustakaan sendiri menurut Sarwono adalah studi yang mempelajari bermacam tulisan atau buku refrensi serta hasil penelitian yang sejenis untuk mendapatkan landasan teori mengenai masalah yang akan diteliti. (Sari and Asmendri 2020)

Studi Pustaka dalam penelitian ini adalah dengan mengumpulkan dari beberapa sumber refrensi tulisan yang didapatkan penulis dari e-book, jurnal, serta penelitian tugas akhir yang akan dijadikan sebagai landasan teoritis dari penelitian ini. Selain itu data yang didapatkan kemudian akan dianalisis dan diolah untuk membentuk hasil pembahasan akhir yang berupa dokumen desain interior untuk studi kasus : Salon dan Spa.

\section{Metode Perancangan}

Salah satu poin yang tercakup dalam penelitian ini adalah desain ruang interior salon dan spa. Oleh karena itu dibutuhkan contoh perancangan sederhana dari interior salon dan spa yang harus dimasukkan ke dalam dokumen desain. Metode perancangan yang akan digunakan untuk penelitian ini seperti yang dituliskan oleh (Setiawan et al. 2016), dan sudah disesuaikan dengan kebutuhan penelitian ini adalah :

Tabel 1 Metode Perancangan Interior Salon dan Spa

\begin{tabular}{|l|l|}
\hline Tahap & Hal yang dilakukan \\
\hline Empathize & $\begin{array}{l}\text { Memahami latar belakang masalah yang berkaitan dengan subjek } \\
\text { perancangan untuk dibuat rumusan masalah. Kemudian mencari }\end{array}$ \\
\hline
\end{tabular}




\begin{tabular}{|l|l|}
\hline & $\begin{array}{l}\text { literatur dan sumber refrensi yang dibutuhkan untuk kebutuhan data } \\
\text { perancangan salon dan spa. }\end{array}$ \\
\hline Define & $\begin{array}{l}\text { Mengamati kebutuhan dan aktivitas pengguna dalam ruang Salon dan } \\
\text { Spa serta membuat programming ruang yang disesuaikan dengan } \\
\text { kebutuhan ruang pengguna }\end{array}$ \\
\hline Ideate & $\begin{array}{l}\text { Membuat konsep dan ide desain yang kemudian dikembangkan untuk } \\
\text { menjadi perancangan desain interior salon dan spa }\end{array}$ \\
\hline Prototype & $\begin{array}{l}\text { Membuat gambar kerja dan 3D Modelling dari desain interior yang } \\
\text { sudah dibuat. Selain itu juga membuat skema material dan warna yang } \\
\text { akan digunakan dalam desain. }\end{array}$ \\
\hline Test & $\begin{array}{l}\text { Membuat produk presentasi untuk dipresentasikan dan dievaluasi } \\
\text { kepada para penguji. }\end{array}$ \\
\hline
\end{tabular}

Sumber : Modifikasi dari (Setiawan et al. 2016)

\section{Metode Penyusunan Dokumen Desain}

Metode yang digunakan dalam penyusunan dokumen desain dalam penelitian ini adalah dengan menentukan susunan dan isi dokumen desain dari literatur yang telah didapatkan dalam bagian studi pustaka. Isi dari dokumen kemudian diaplikasikan dalam satu studi kasus perancangan interior untuk menjadi contoh pembuatan dokumen desain yang dalam penelitian ini adalah perancangan interior salon dan spa.

\section{Hasil dan Pembahasan}

\section{Dokumen Desain}

(Nur Z 2010) menjelaskan bahwa Dokumen desain adalah media yang digunakan oleh konsultan perencana untuk diwujudkan ke dalam struktur fisik bangunan. Dokumen desain merupakan alat komunikasi antara konsultan perencana dengan kontraktor berhubungan dengan desain yang akan dibangun. Dokumen desain pada umumnya disampaikan dalam bentuk gambar konstruksi dan spesifikasi (RKS).

1. Gambar konstruksi / Gambar Kerja

Gambar kerja digunakan oleh semua yang terlibat dalam sebuah proyek untuk bekerja pada bangunan yang sebenarnya dari desain yang telah dibuat sebelumnya. Gambar menunjukkan aspek-aspek fisik struktur, pengaturan, dimensi, letaknya, serta detail konstruksi, dan informasi penting lainnya untuk membangun suatu proyek.

\section{Rencana Kerja dan Syarat / RKS}

Spesifikasi yang tertulis dalam RKS merupakan instrumen tertulis yang berhubungan dengan keperluan proyek. Sebagai contoh, warna cat yang akan diterapkan pada dinding bangunan akan terdaftar dengan nama produsen, nomor telepon, nomor warna cat dan nama, dan jenis finishing yang akan digunakan.

Sementara di dalam (IFC et al. 2020), Dokumen arahan produksi atau penjelasan desain digunakan untuk melengkapi desain akhir. Isi dari dokumen ini bisa termasuk design rationale, brand guidelines, panduan teknis, gambar kerja, skema material, dan arahan produksi. Tidak jarang pula pada tahapan ini, karya desain akhir juga diwujudkan dalam bentuk model/mockup dan purwarupa dalam jumlah terbatas sebagai contoh atau arahan produksi. Purwarupa adalah prototype atau arketipe merupakan bentuk awal atau contoh dari suatu model (Azis and Dirgahayu 2015) 
Dokumen tersebut harus disiapkan secara cermat dan teliti, menjelaskan proses dan hasil dari tahapan-tahapan yang telah dilakukan dari awal sampai dengan hasil akhir dari keseluruhan kegiatan pekerjaan desain agar dapat dipahami dengan baik oleh klien. Berikut adalah contoh-contoh gambar purwarupa yang termasuk dalam Dokumen penjelasan desain Interior.

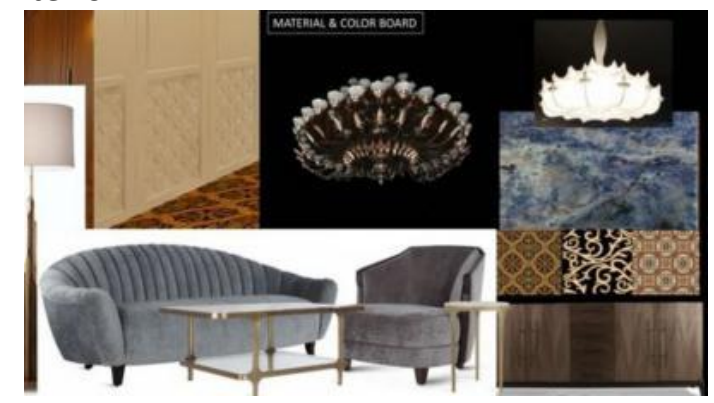

Gambar 1 Contoh Gambar Purwarupa Desain Interior 1 Sumber : (IFC et al. 2020)

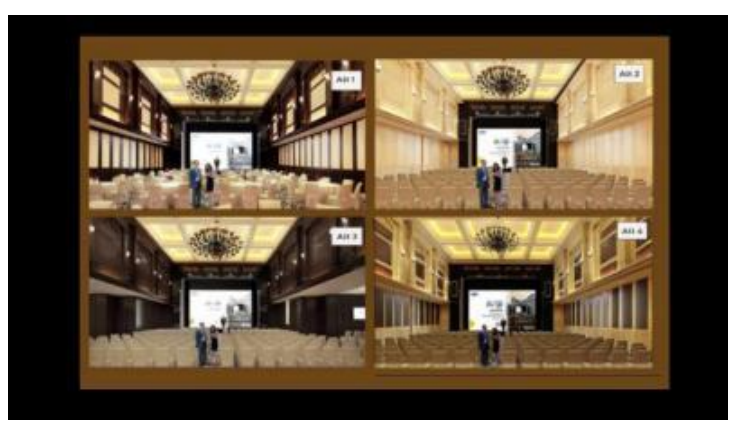

Gambar 2 Contoh Gambar Purwarupa Desain Interior 2 Sumber : (IFC et al. 2020)

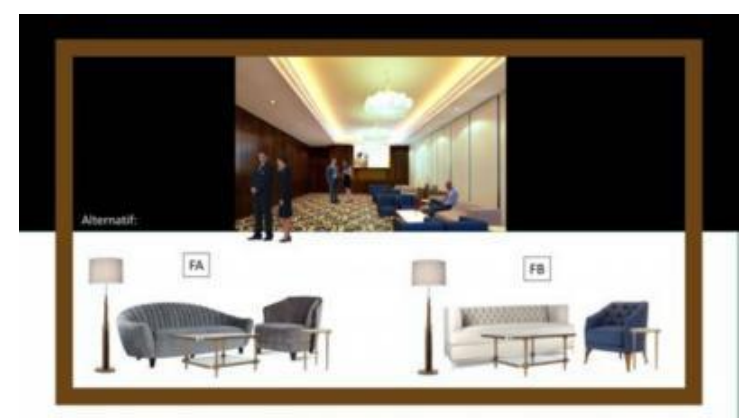

Gambar 3 Contoh Gambar Purwarupa Desain Interior 3 Sumber : (IFC et al. 2020)

Sementara, dalam Lampiran Persyaratan Pengajuan SKA ( Sertifikat Keahlian ) Muda organisasi HDII (Himpunan Desainer Interior Indonesia) yang ditulis dalam laporan proyek dokumen desain oleh (Prianto 2020),pada setiap proyek desain yang diajukan mencakup beberapa hal sebagai berikut :

1. Pelaksanaan Sistem Manajemen Keselamatan, Kesehatan Kerja dan Lingkungan (SMKL3)

Dalam modul yang terdapat diS (Pendidikan Pusat Pelatihan Sumber Daya dan Air 2017), Pengendalian resiko kecelakaan dan penyakit akibat kerja dalam proses rekayasa harus dimulai sejak tahapan perancangan dan perencanaan. Setiap tahap dari siklus perancangan meliputi:
a. Pengembangan
b. Verifikasi tinjauan ulang 
Pada bagian Perancangan dan Rekayasa, orang yang menangani harus memiliki kompetensi kerja yang sesuai dan diberikan wewenang serta tanggung jawab yang jelas untuk melakukan validasi persyaratan SMK3. Dalam proses mendesain interior, para desainer interior-lah yang bertugas memperhatikan persyaratan SMKL3 yang akan berpengaruh untuk keselamatan dan kesehatan pengguna ruang.

2. Metode dan Teknik Pengumpulan Data

Secara prinsip ada dua cara mendapatkan data lapangan, yaitu dengan pengumpulan data primer dan data sekunder. Beberapa yang termasuk dalam pengumpulan data primer antara lain adalah : survei lapangan dengan meninjau lokasi pengukuran dan survei lapangan dengan mengamati kondisi eksisting interior - proyek renovasi. Sementara Pengumpulan data sekunder adalah mencari referensi standart besaran ruang maupun definisi/konsep suatu ruang dan mendapatkan dokumen kebutuhan ruangan dan perlengkapannya dari pemilik proyek ( Bisa berupa KAK ) (Prianto 2020)

3. Data Pra-Rancangan

Data Pra-Rancangan berisi konsep desain yang menjelaskan desain yang akan dibuat, dan kemudian disusun di dalam proposal desain dan dilengkapi juga dengan 3D Perspektif untuk memberikan gambaran hasil desain (Prianto 2020). Proposal desain digunakan oleh para perancang mulai dari perancang freelance, biro desain, atau bisnis desain lainnya. Ini dikirim ke calon klien desain untuk memberikan rincian tentang desain dan kerja branding. (Spencer 2020)

4. Data Rancangan

Pada bagian data rancangan berisi hal - hal yang direncanakan untuk diperhatikan rancangannya dalam mendesain ruang interior (Prianto 2020). Bagian - bagian yang dimaksud adalah :

a. Rancangan Layout Furniture

b. Rancangan Floorplan

c. Rancangan Partition plan

d. Rancangan M\&E Plan

e. Mengembangkan Detail Interior

f. Mengembangkan Detail Furniture

g. Mengembangkan Detail Penunjang

5. Dokumen Pelaksanaan

Dokumen Pelaksanaan berisi dokumen yang membantu dalam pelaksanaan atau pengerjaan desain di lapangan. Dokumen pelaksanaan berisi :

a. Gambar DED

Gambar DED berisi gambar kerja yang terdiri dari gambar kerja yang mempresentasikan bagian-bagian pada data rancangan sehingga mempermudah petugas yang mengeksekusi desain pada saat di lapangan.

b. RKS Administrasi dan Teknis

RKS atau bestek adalah keterangan tertulis secara terperinci mengenai suatu pekerjaan yang mencakup segi teknis dan administratif. Uraian dalam RKS harus dibuat se-lengkap mungkin dengan maksud agar di dalam pelaksanaan pekerjaan tidak timbul 
kesulitan (Balai Penerapan Teknologi Konstruksi 2018). RKS terdiri dari tiga bagian yaitu : Syarat Umum, Administrasi dan Teknis

c. Rencana Anggaran Biaya (RAB)

Rencana anggaran biaya suatu bangunan atau Proyek adalah perhitungan banyaknya biaya yang diperlukan untuk bahan dan upah, serta biaya- biaya lain yang berhubungan dengan pelaksanaan bangunan dan proyek tersebut. Penyusunan Anggaran biaya terdapat dua cara yaitu anggaran biaya kasar anggaran biaya teliti. (Balai Penerapan Teknologi Konstruksi 2018)

d. Jadwal Pelaksanaan

Jadwal pelaksanaan proyek digunakan untuk menetapkan jangka waktu kegiatan proyek yang harus diselesaikan. Beberapa manfaat dibuatnya jadwal pelaksanaan proyek adalah mengidentifikasi tahapan urutan kegiatan, menampilkan biaya untuk tiap kegiatan, hingga menunjukkan kebutuhan material dan peralatan dalam pelaksanaan. (Balai Penerapan Teknologi Konstruksi 2018)

6. Pengawasan Berkala

Menurut (Legowo and Nurcahyo 2018) dalam hal desain interior, seorang desainer mempunyai wewenang sebagai pengawas, beberapa haknya antara lain adalah:

a. Mengetahui dan memberi persetujuan atas penilaian konsultan pengawas terhadap pekerjaan kontraktor, sehingga kontraktor mendapatkan haknya atas tahap pembayaran sesuai dengan prestasi yang telah dicapai.

b. Wewenang menolak hasil kerja Kontraktor.

c. Desainer Interior berhak menolak hasil pekerjaan yang ternyata tidak sesuai dengan desain interior dan wajib memberikan solusi dilapangan melalui rapat koordinasi dengan konsultan pengawas.

7. Laporan Pekerjaan

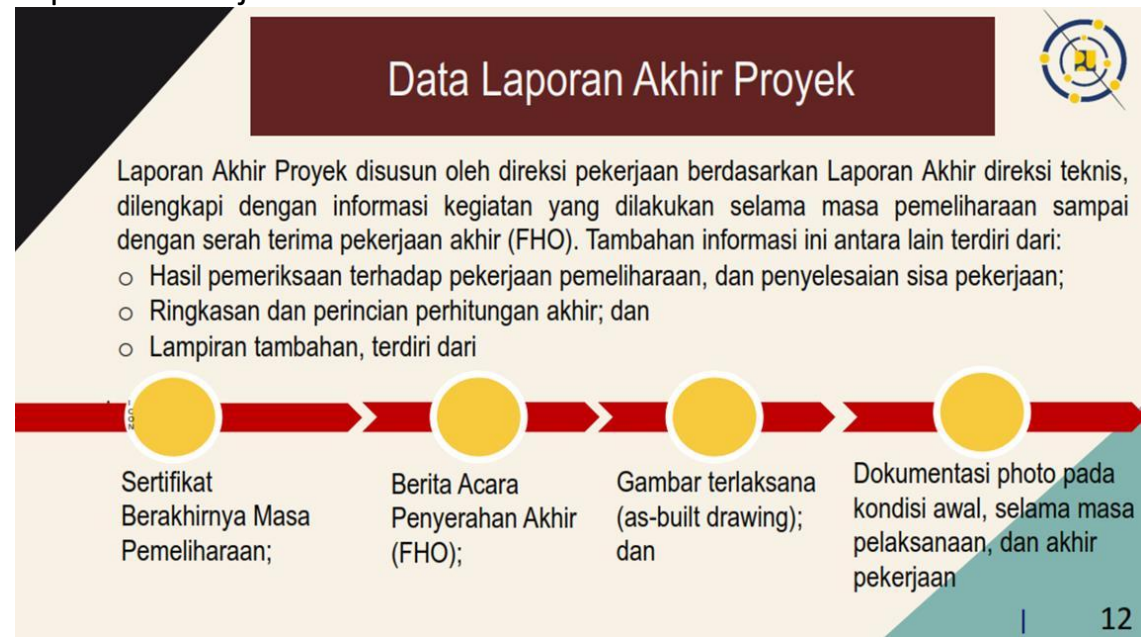

Gambar 4 Laporan Akhir Proyek Sumber : (Prianto 2020)

\section{Desain Interior}

"Interior design is the planning, layout, and design of the interior spaces within buildings. These physical settings satisfy human's basic need for shelter and protection, set the stage for and influence the shape of our activities, nurture our aspirations, express the ideas that accompany our actions, and affect our outlook, mood, and personality. The purpose of 
interior design, therefore, is the functional improvement, aesthetic enrichment, and psychological enhancement of the quality of life in interior spaces." (Ching and Binggeli 2012)

Inti dari pernyataan Ching di atas adalah desain interior dilakukan dengan tujuan untuk menata dan mengatur ruang dalam bangunan untuk memenuhi kebutuhan pengguna di dalamnya, dari segi fisik seperti spasial/ruang untuk aktivitas dan psikologis. la juga menyebutkan bahwa dalam mendefinisikan dan menganalisis masalah desain, kita juga harus mengetahui tujuan dan kriteria yang efektif untuk solusi dari permasalahan yang terjadi. Terlepas dari sifat masalah desain interior yang sedang ditangani, ada beberapa kriteria yang harus kita perhatikan, yaitu :

1. Function and Purpose

2. Utility, Economy, and Sustainability

3. Form and Style

4. Image and Meaning

Proses Perancangan

Objek Perancangan

Fasilitas yang bersifat leisure seperti salon dan spa dibutuhkan oleh masyarakat yang mempunyai sedikit waktu untuk bersantai dan berelaksasi. Seperti contoh adalah masyarakat urban atau perkotaan yang memiliki tingkat kesibukan yang tinggi sehingga tidak mempunyai banyak waktu untuk memanjakan dan merelaksasikan diri. Karena secara fisik, salah satu tanda kehidupan masyarakat di perkotaan adalah kemacetan dari kesibukan masyarakatnya. (Jamaludin 2015). Ruang yang akan dibentuk merupakan ruang virtual, virtual sendiri berarti tiruan atau replika digital yang cukup mirip dengan sesuatu yang nyata. (Sudirman 2020)

1. Salon

Berdasarkan (KBBI Online n.d.), Salon adalah ruang yang diatur dan dihias dengan baik (untuk menerima tamu dan sebagainya) atau tempat gedung sebagai tempat orang untuk merawat kecantikan seperti merias muka, merawat rambut dan sebagainya. Karena sifatnya sebagai tempat merawat kecantikan, maka salon juga tidak sering disebut sebagai salon kecantikan.

Menurut Kusumadewi dalam (Pebrina, Hayatunnufus, and Yanita 2016) berpendapat bahwa salon kecantikan adalah tempat pelayanan umum untuk merawat kesehatan rambut dan kulit dengan perawatan kosmetik yang modern maupun tradisional tanpa tindakan operasi dan bedah. Sementar menurut (Peraturan Direktur Jenderal Bina Gizi Kesehatan Ibu dan Anak 2011), Salon kecantikan adalah fasilitas pelayanan untuk memperbaiki penampilan melalui tata rias dan pemeliharaan kecantikan kulit dan rambut dengan menggunakan kosmetik secara manual, preparatif, aparatif, dan dekoratif, dan dilakukan oleh ahli kecantikan sesuai kompetensi yang dimiliki. Salon kecantikan diklasifikasikan berdasarkan kewenangan dan persyaratan minimal yang dimiliki, yaitu :
a. Tipe Pratama
b. Tipe Madya
c. Tipe Utama

2. Spa

Pengertian Pelayanan Kesehatan SPA seperti yang tertulis dalam (Peraturan Menteri Kesehatan RI 2014) adalah pelayanan kesehatan yang dilakukan secara holistik dengan memadukan berbagai jenis perawatan kesehatan tradisional dan modern yang menggunakan air beserta pendukung perawatan lainnya berupa pijat penggunaan ramuan, terapi aroma, latihan fisik, terapi warna, terapi musik, dan makanan untuk memberikan efek terapi melalui panca indera guna mencapai keseimbangan antara tubuh (body), 
pikiran (mind), dan jiwa (spirit), sehingga terwujud kondisi kesehatan yang optimal. Pelayanan Kesehatan Spa dibagi menjadi dua kategori :

a. Health Spa : Pelayanan spa untuk menghasilkan manfaat relaksasi yaitu mengurangi kelelahan, ketegangan dan emosi fisik maupun mental dan mendapatkan kebugaran kembali. Spa jenis ini dilaksanakan pada Griya SPA tirta I

b. Wellness Spa : Pelayanan spa untuk menghasilkan manfaat peremajaan (rejuvinasi) dan penguatan sistem dan organ tubuh sehingga mendapatkan kesehatan yang lebih optimal (revitalisasi). Spa jenis ini dilaksanakan pada Griya SPA tirta II dan III.

Berikut pilihan jenis Salon dan Spa yang akan di desain dalam penelitian ini :

1. Beauty Salon Tipe Pratama

Tabel 2 Klasifikasi Salon Untuk Penelitian

\begin{tabular}{|c|c|c|}
\hline Jenis Salon & \multirow{2}{*}{\multicolumn{2}{|c|}{$\begin{array}{l}\text { Fasilitas Salon (Tipe Pratama) } \\
\text { (Peraturan Direktur Jenderal Bina Gizi Kesehatan Ibu dan Anak } \\
\text { 2011) }\end{array}$}} \\
\hline \multirow{9}{*}{$\begin{array}{l}\text { Hair Styling Salon, Hair Salon } \\
\text { menawarkan servis khusus yang } \\
\text { berhubungan dengan perawatan } \\
\text { rambut saja, seperti pemangkasan } \\
\text { rambut, penataan, pewarnaan, } \\
\text { pencucian dan perawatan spesial } \\
\text { seperti penyambungan rambut } \\
\text { (hair extensions) atau penghilangan } \\
\text { rambut di daerah tertentu (hair } \\
\text { removal).(Prabasari et al. 2018) }\end{array}$} & & \\
\hline & 1. & Perawatan wajah tidak bermasalah \\
\hline & 2. & Periasan wajah untuk siang dan malam hari \\
\hline & 3. & $\begin{array}{l}\text { Merawat tangan dan mewarnai kuku (menicure) } \\
\text { Merawat kaki dan mewarnai kuku (pedicure) }\end{array}$ \\
\hline & \multicolumn{2}{|c|}{ Perawatan Rambut } \\
\hline & 1. & Mencuci Rambut \\
\hline & 2. & Merawat kulit kepala dan rambut \\
\hline & 3. & Mengeringkan rambut dengan alat pengering \\
\hline & 4. & Menata Sanggul Hair Piece \\
\hline
\end{tabular}

2. Health Spa dengan fasilitas Griya Tirta I

Tabel 3 Klasifikasi Spa Untuk Penelitian

\begin{tabular}{|c|c|c|}
\hline Jenis Spa & & $\begin{array}{l}\text { Fasilitas Spa (Gol. Griya Tirta I) } \\
\text { (Peraturan Menteri Pariwisata 2019) }\end{array}$ \\
\hline \multirow{6}{*}{$\begin{array}{l}\text { Health Spa, yang berfokus untuk } \\
\text { relaksasi dengan manfaat untuk } \\
\text { mengurangi kelelahan, ketegangan } \\
\text { dan emosi fisik maupun mental dan } \\
\text { mendapatkan kebugaran kembali. } \\
\text { Spa jenis ini dilaksanakan pada Griya } \\
\text { SPA Tirta I }\end{array}$} & \multicolumn{2}{|c|}{ Perawatan } \\
\hline & 1. & $\begin{array}{l}\text { Terapi Air ( Hydrotherapy) : Berendam dan Mandi } \\
\text { Uap }\end{array}$ \\
\hline & 2. & $\begin{array}{l}\text { Terapi Aroma (Aromatherapy) paling sedikit } \\
\text { menggunakan } 5 \text { jenis minyak Astiri khas Indonesia } \\
\text { untuk merelaksasi }\end{array}$ \\
\hline & 1. & Terapi Pijat (massage) tradisional Indonesia \\
\hline & 2. & Perawatan Wajah ( Facial ) tanpa alat \\
\hline & 3. & $\begin{array}{l}\text { Perawatan Kaki (Foot-spa) dan Tangan (Hand-spa) } \\
\text { tanpa alat }\end{array}$ \\
\hline
\end{tabular}

Salon dan Spa dengan jenis di atas dipilih karena perancangan dalam penelitian ini dimaksudkan hanya sebagai contoh dalam pembuatan dokumen maka dipilihlah jenis di atas yang merupakan jenis paling sederhana dalam klasifikasi salon dan spa yang sebelumnya sudah dibahas di atas.

\section{Kebutuhan Ruang}

Kebutuhan ruang berisi total ruang ruang yang dibutuhkan berdasarkan jenis Salon dan Spa yang telah disebutkan serta dipengaruhi oleh aktivitas yang dilakukan oleh pengguna pengguna salon dan spa selama pelayanan. Total Kebutuhan Ruang ini kemudian akan 
digunakan untuk menghasilkan ukuran luas ruang virtual yang akan dijadikan lokasi perancangan salon dan spa.

Tabel 4 Analisis Perhitungan Kebutuhan Ruang

\begin{tabular}{|c|c|c|c|c|c|c|}
\hline No. & Nama Ruang & Kapasitas & Jumlah & Luas $\left(m^{2}\right)$ & $J x L$ & Total $\left(\mathrm{m}^{2}\right)$ \\
\hline 1. & \multicolumn{6}{|c|}{ Ruang Perawatan Spa } \\
\hline & \multirow{4}{*}{$\begin{array}{l}\text { Ruang Perawatan } \\
\text { Terapi Air }\end{array}$} & Bak Rendam (Bathub) & 2 & 1,7 & 3,4 & \multirow{4}{*}{11,9} \\
\hline & & Alat Steam (Steamer) & 2 & 1,2 & 2,1 & \\
\hline & & Rak Penyimpanan Barang & 2 & 0,2 & 0,4 & \\
\hline & & \multicolumn{3}{|l|}{ Sirkulasi $100 \%$} & 5,9 & \\
\hline & \multirow{3}{*}{$\begin{array}{l}\text { Ruang Perawatan } \\
\text { Terapi Pijat dan } \\
\text { Wajah }\end{array}$} & Tempat tidur Pijat & 2 & 1,3 & 2,6 & \multirow{3}{*}{5,8} \\
\hline & & Lampu Facial & 2 & 0,1 & 0,3 & \\
\hline & & Sirkulasi $100 \%$ & & & 2,9 & \\
\hline 2. & \multicolumn{6}{|c|}{ Ruang Penerimaan Tamu } \\
\hline & \multirow{3}{*}{ Receptionist } & Meja Receptionist & 1 & 1,4 & 1,4 & \multirow{3}{*}{4,2} \\
\hline & & Kursi Duduk & 2 & 0,3 & 0,6 & \\
\hline & & \multicolumn{3}{|l|}{ Sirkulasi $100 \%$} & 2,0 & \\
\hline & \multirow{4}{*}{ Ruang Duduk } & Sofa Double & 1 & 1,8 & 1,8 & \multirow{4}{*}{8,8} \\
\hline & & Sofa Single & 2 & 0,9 & 1,9 & \\
\hline & & Meja Tamu & 1 & 0,7 & 0,7 & \\
\hline & & \multicolumn{3}{|l|}{ Sirkulasi $100 \%$} & 4,4 & \\
\hline \multirow[t]{5}{*}{3.} & \multicolumn{6}{|c|}{ Ruang Styling Rambut } \\
\hline & & Kursi Perawatan Rambut & 3 & 0,8 & 2,5 & \multirow{4}{*}{12,8} \\
\hline & & Bak Cuci Rambut & 2 & 1,6 & 3,2 & \\
\hline & & Rak Alat Salon & 3 & 0,2 & 0,6 & \\
\hline & & Sirkulasi $100 \%$ & & & 6,4 & \\
\hline 4. & Ruang Minum & & & & & \\
\hline & & Meja 2 Orang & 2 & 1,1 & 2,1 & \multirow{4}{*}{33,2} \\
\hline & & Meja Bar 4 Orang & 1 & 2,5 & 2,5 & \\
\hline & & Pantry & 1 & 12,0 & 12,0 & \\
\hline & & Sirkulasi $100 \%$ & & & 16,6 & \\
\hline 4. & \multicolumn{2}{|c|}{ Ruang Bilas ( 2 Kamar ) } & 2 & 4,8 & 9,7 & 9,7 \\
\hline 5. & \multicolumn{2}{|l|}{ Toilet } & 2 & 2,0 & 4,0 & 4,1 \\
\hline 6. & \multicolumn{2}{|l|}{ Ruang Loker } & 1 & 9,4 & 9,4 & 9,4 \\
\hline 7. & \multicolumn{2}{|c|}{ Gudang Penyimpanan } & 1 & 3,5 & 3,5 & 3,5 \\
\hline 8. & \multicolumn{6}{|c|}{ Ruang Kantor Manajer } \\
\hline & & Meja Manajer & 1 & 1,8 & 1,8 & \multirow{3}{*}{4,9} \\
\hline & & Kursi Duduk & 2 & 0,3 & 0,6 & \\
\hline & & Sirkulasi $100 \%$ & & & 2,4 & \\
\hline \multicolumn{6}{|c|}{ Sub Total } & 108,3 \\
\hline \multicolumn{6}{|c|}{ Sirkulasi $100 \%$} & 108,3 \\
\hline \multicolumn{6}{|c|}{ TOTAL } & 216,6 \\
\hline
\end{tabular}

Sumber : Dokumen Pribadi, 2021

Bentuk dan Luas Ruang

Dari perhitungan kebutuhan ruang pengguna pada sub bab sebelumnya dapat diketahui bahwa total luas ruang virtual yang dibutuhkan untuk perancangan interior salon dan spa pada penelitian ini adalah sebesar $216 \mathrm{~m}^{2}$, dengan ruang berukuran $18 \mathrm{~m} \times 12 \mathrm{~m}$ 


\section{Programming Ruang}

Dari jenis-jenis ruang yang dibutuhkan dan tertulis pada tabel di atas, maka dibuatlah programming ruang yang berisi hubungan antar ruang yang nantinya akan membentuk zoning ruang salon dan spa.

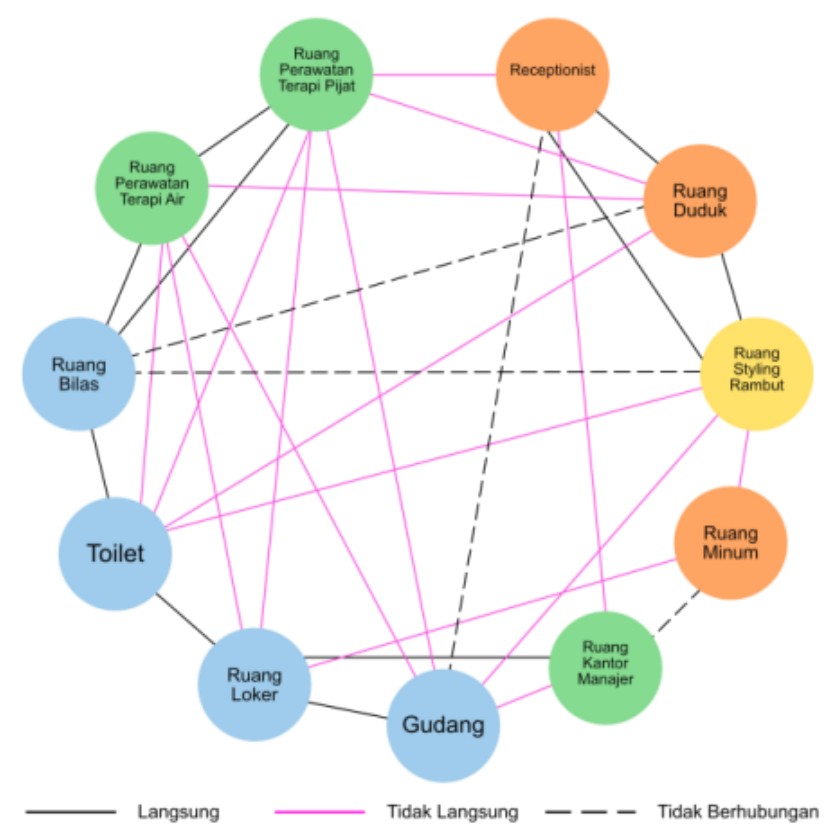

\begin{tabular}{l|lll} 
Ruang Privat & Ruang Semi Privat & Ruang Publik & Ruang Servis
\end{tabular}

Gambar 5 Hubungan Antar Ruang

Sumber : Dokumen Pribadi, 2021

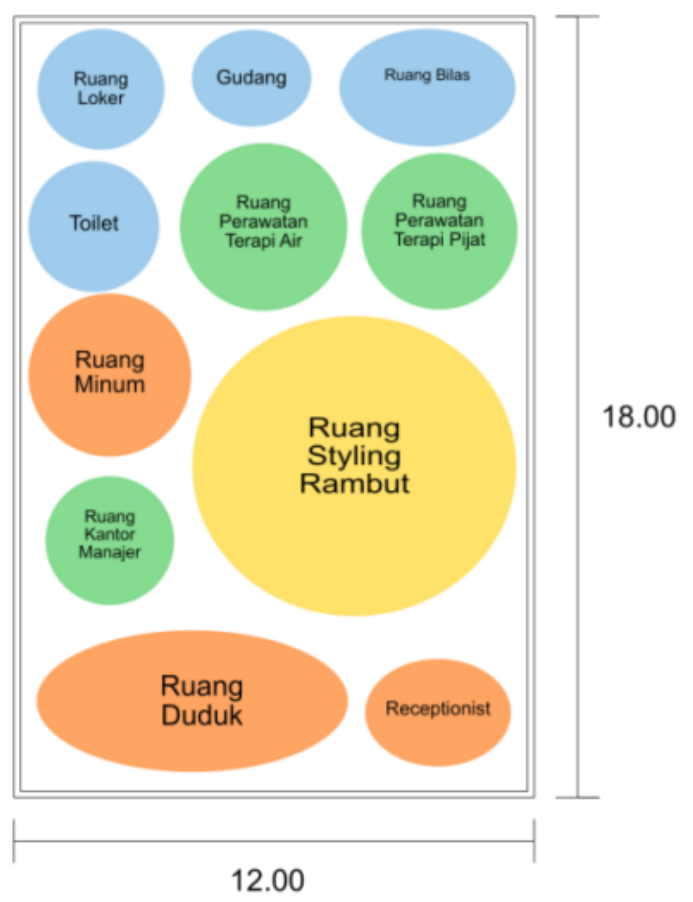

Gambar 6 Zoning Ruang

Sumber : Dokumen Pribadi, 2021 
Penyusunan Dokumen Desain

Mengetahui Sistem Manajemen Keselamatan Kesehatan (SMK3L)

Penerapan Sistem Manajemen Keselamatan Kesehatan (SMK3L)

1. Salon

Berdasarkan yang tertulis pada (Peraturan Direktur Jenderal Bina Gizi Kesehatan Ibu dan Anak 2011), fasilitas yang harus ada pada fasilitas salon kecantikan adalah sebagai berikut :

a. Fasilitas Umum : Bangunan bersih utnuk mencegah kemungkinan terjadi penularan penyakit dan atau kecelakaan, pembagian ruangan yang jelas sesuai dengan fungsinya,bangunan tidak menimbulkan gangguan terhadap lingkungan dan tidak terganggu oleh keadaan di sekitarnya

b. Fasilitas Khusus, beberapa di antaranya adalah : Lantai Kedap air, rata, tidak licin serta mudah dibersihkan, dinding atau penyekat sebelah dalam rata, berwarna terang serta mudah dibersihkan, langit - langit berwarna terang, mudah dibersihkan dengan tinggi dari lantai minimal 2,5 meter, atap kuat dan tidak bocor serta ventilasi yang dapat menjamin pergantian udara dengan baik atau luas ventilasi minimal $5 \%$ dari luas lantai, namun bila ruangan dilengkapi dengan $\mathrm{AC}$, ventilasi tidak diperlukan.

2. Spa

Berdasarkan yang tertulis pada (Peraturan Menteri Kesehatan RI 2014), fasilitas yang harus ada pada fasilitas salon kecantikan adalah sebagai berikut :

a. Ventilasi : Ventilasi menjamin peredaran udara di dalam ruang dengan baik. ( pertukaran udara minimal $12 \mathrm{kali} / \mathrm{jam}$ ). Luas ventilasi alamiah yang disarankan sebesar $15 \%$ dari luas lantai ruangan.

b. Pencahayaan : Intensitas cahaya memenuhi syarat untuk melakukan kegiatan dengan memerlukan sedikit ketelitian seperti perawatan tubuh dengan pencahayaan minimal sebesar 500lux.

c. Toilet : Toilet perempuan dan laki - laki harus dipisah, tersedia sanitasi toilet dan dilengkapi tempat cuci tangan dan sabun, tersedia air bersih dan alat kebersihan (sabun, tissue, handuk) yang cukup, permukaan lantai kedap air, tidak licin, dan rata kecuali dengan kemiringan maksimal $3^{\circ}$ untuk pembuangan air kotor, suhu ruangan berkisar antara $22^{\circ}$ hingga $250^{\circ} \mathrm{C}$, kelembaban berkisar antara $40 \%-70 \%$, indeks jentik nyamuk tidak lebih dari $5 \%$, serta tingkat kebisingan tidak melebihi $85 \mathrm{~dB}$.

\section{Pemahaman Tahapan Studi dan Kelayakan Data}

1. Teknik Pengumpulan Data

Data yang digunakan dalam pembuatan dokumen desain interior salon dan spa ini adalah data sekunder yang diperoleh dari studi pustaka sumber literatur seperti standar Ruang dan Furniture dari E-Book serta beberapa JurnalPerancangan Interior yang sebelumnya telah dipublish oleh peneliti lain untuk dijadikan refrensi perancangan

2. Analisis dan Pengolahan Data

Analisis dan pengolahan data yang dilakukan dalam pembuatan dokumen desain interior salon dan spa ini adalah mengubah hasil studi pustaka untuk dianalisis menjadi desain interior yang paling cocok diterapkan berdasarkan data yang sudah diperoleh, produknya berupa analisis desain interior untuk Salon dan Spa. Kemudian hasil dari perancangan dimasukkan ke dalam dokumen desain. 


\section{Tahapan Pra-Rancangan}

\section{Konsep Desain}

Konsep untuk perancangan salon dan spa ini adalah 'Nature' yang berkaitan dengan alam untuk menghadirkan suasana yang sejuk, santai serta menenangkan untuk merelaksasi diri bagi para pengunjung ketika mendapatkan pelayanan di dalam salon dan spa.
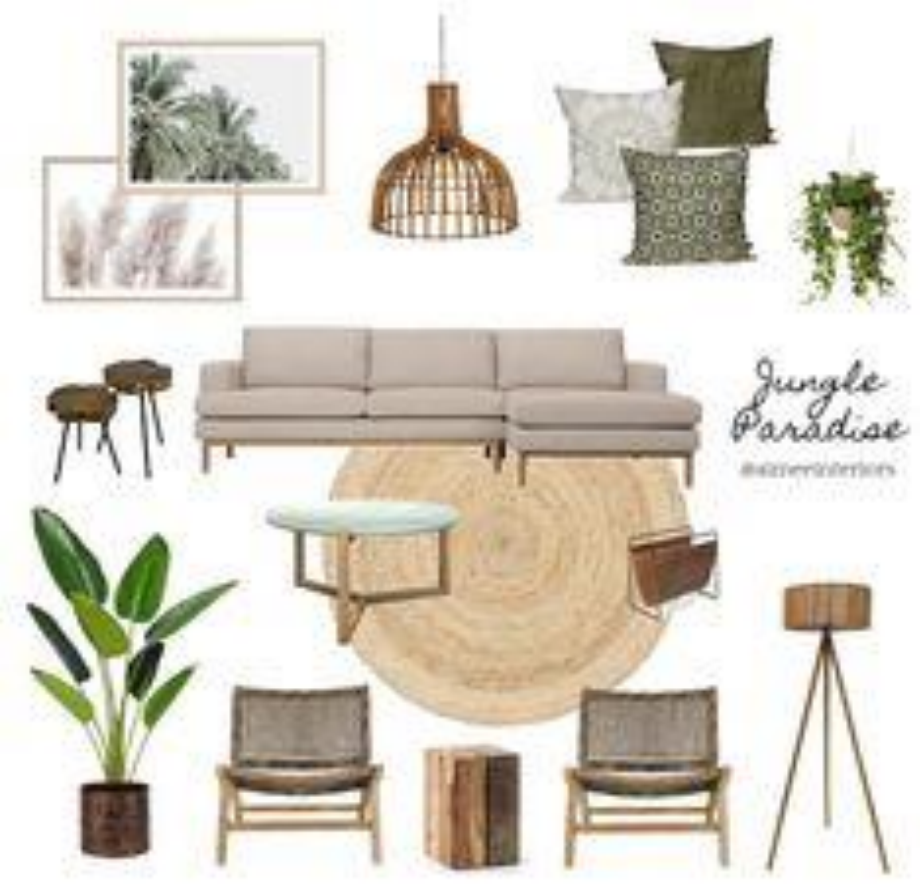

Gambar 7 Illustrasi Konsep Natural

Sumber : (Aimee \& Co. Interior Styling 2019)

2. Proposal Desain

Proposal desain yang digunakan pada penelitian ini adalah proposal untuk pengajuan desain interior proyek salon dan spa.

3. Gambar Perspektif 3 Dimensi

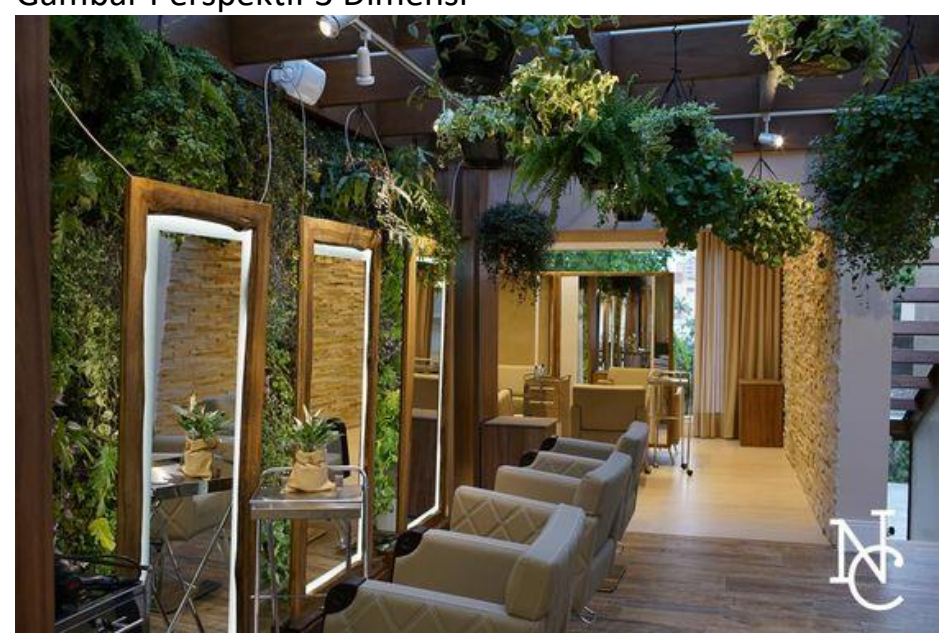

Gambar 8 Illustrasi Gambar 3D Perspektif Ruang Salon Sumber : (Van De Velde n.d.) 


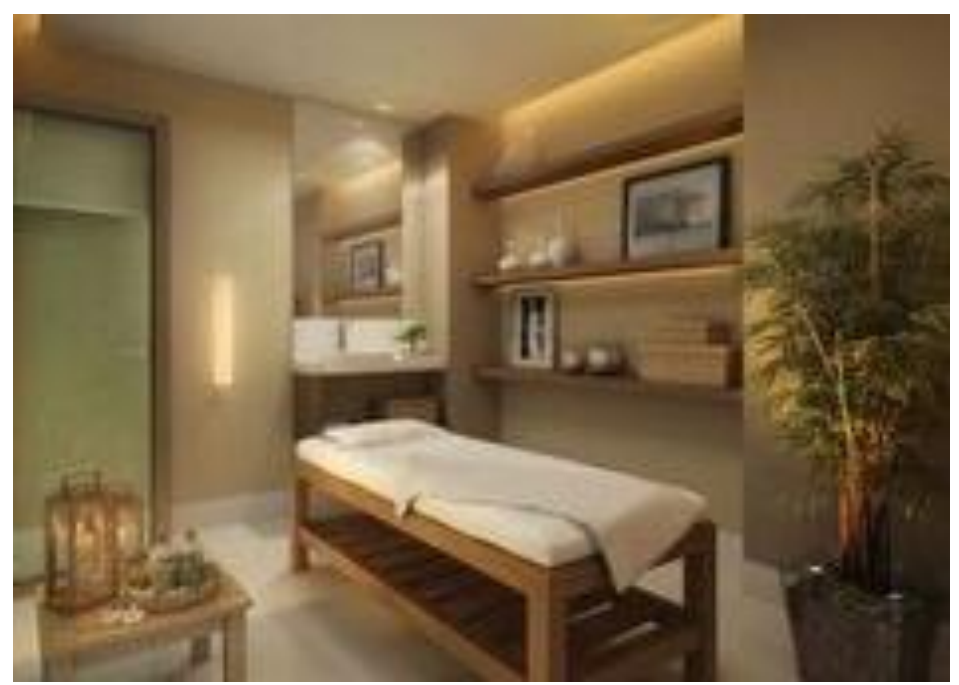

Gambar 9 Illustrasi Gambar 3D Perspektif Ruang Spa

Sumber : (Cuendias 2016)

\section{Membuat Rancangan}

1. Membuat Rancangan

Pada tahap ini mulai membuat gambar kerja dan perspektif berdasarkan konsep dan programming ruang yang sudah dibuat sebelumnya. Gambar - gambar ini kemudian akan dijadikan acuan kepada pelaksana lapangan sebelum merealisasikan desain tersebut. Gambar Kerja yang akan dibuat untuk melengkapi perancangan untuk ruang salon dan spa adalah :
a. Floorplan Ruang Salon dan Spa
b. Layout Furniture Ruang Salon dan Spa
c. Ceiling Plan
d. Partition Plan
e. M\&E Plan
f. Detail Interior dan Furnitur

2. Mengembangkan Rancangan Spesifikasi Material dan Warna

a. Detail Interior

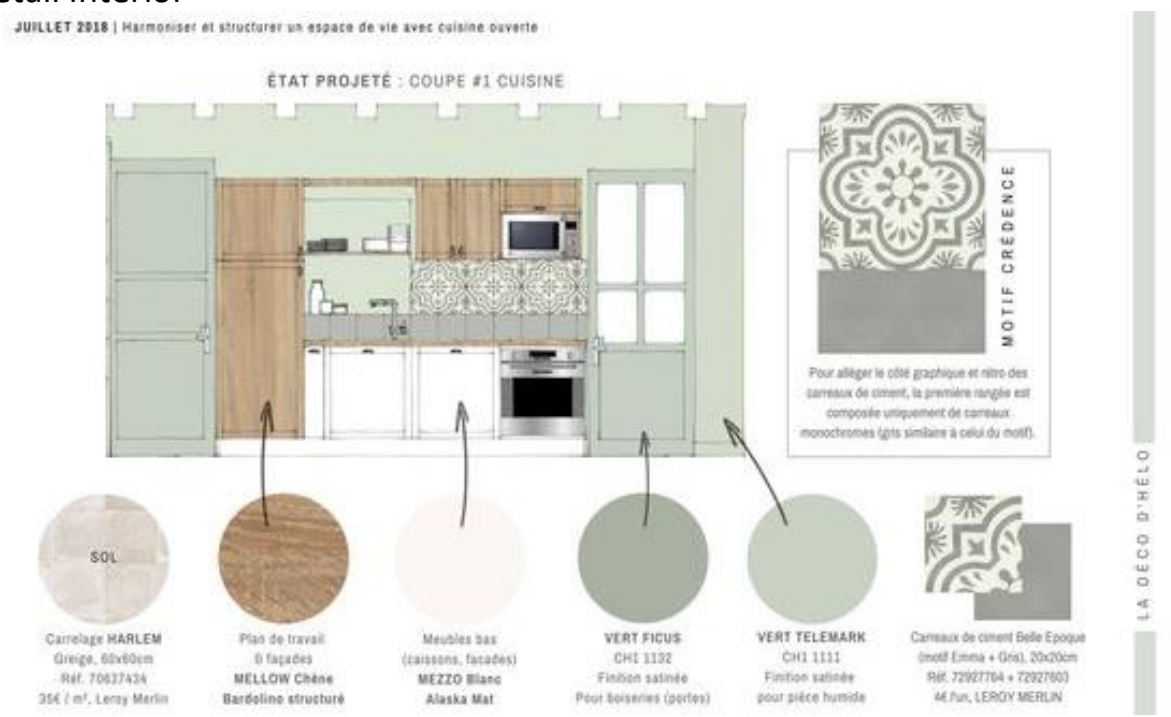

Gambar 10 Illustrasi Gambar Detail Material Interior Sumber : (Juillet 2018) 
b. Detail Furniture

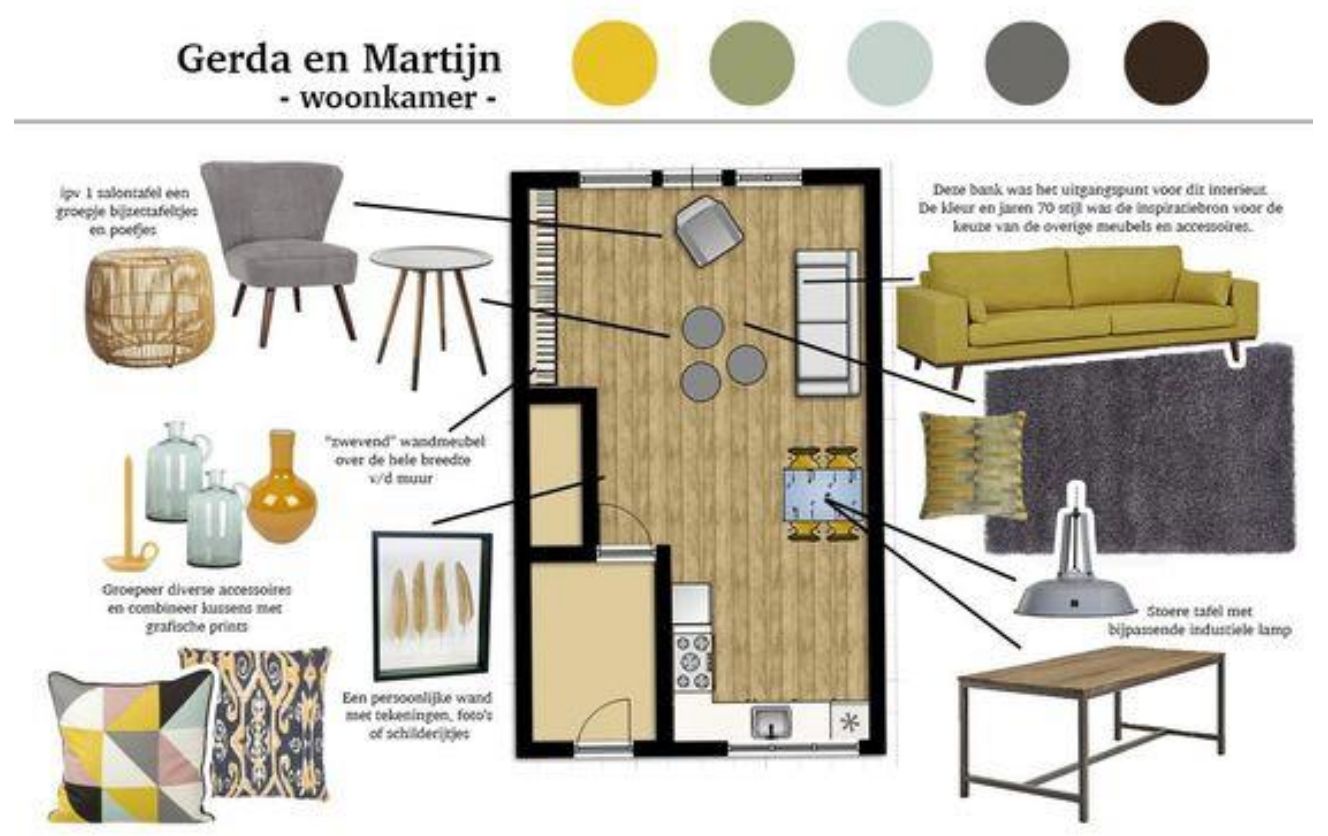

Gambar 11 Illustrasi Gambar Detail Material Furniture

Sumber : (Create Wow 2018)

Mengerti dan Memahami Dokumen Pelaksanaan

Membuat Dokumen Pelaksanaan

1. Gambar Kerja (DED)

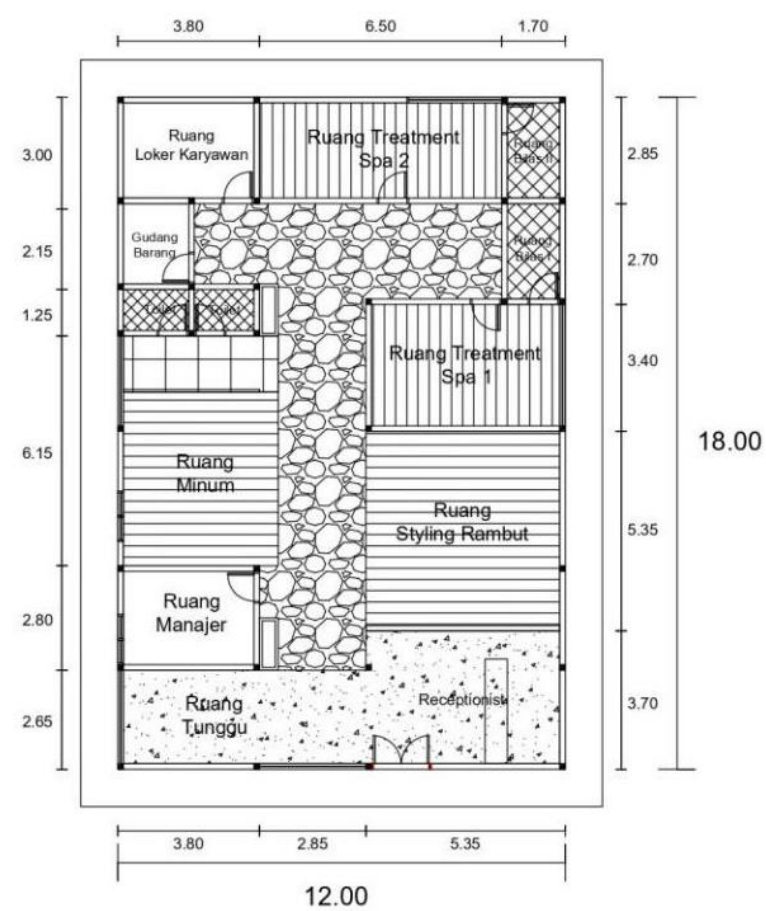

Gambar 12 Gambar FloorPlan untuk Perancangan Salon dan Spa Sumber : Dokumen Pribadi, 2021 


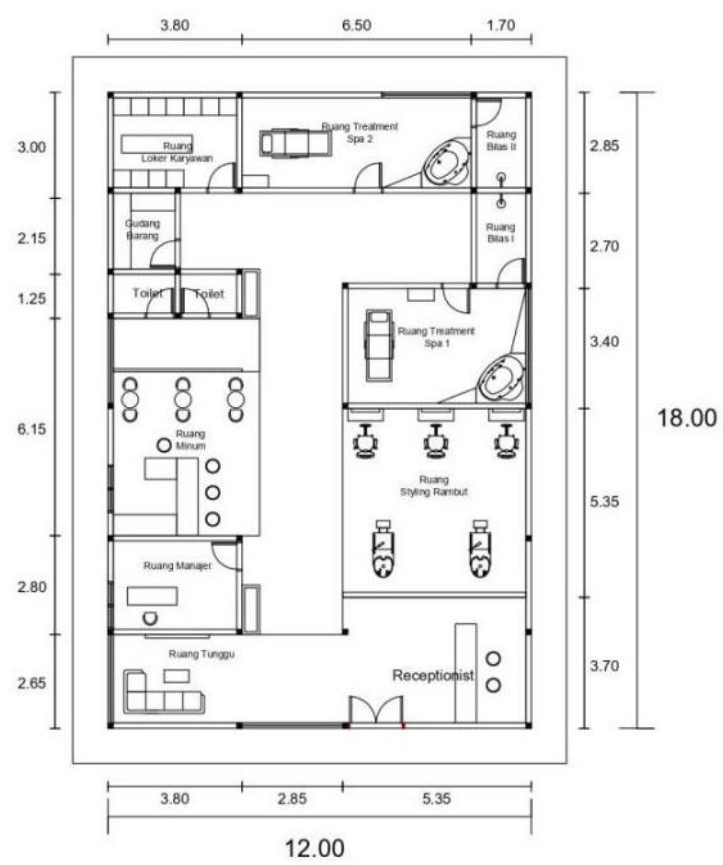

Gambar 13 Gambar Layout Furniture untuk Perancangan Salon dan Spa Sumber : Dokumen Pribadi, 2021

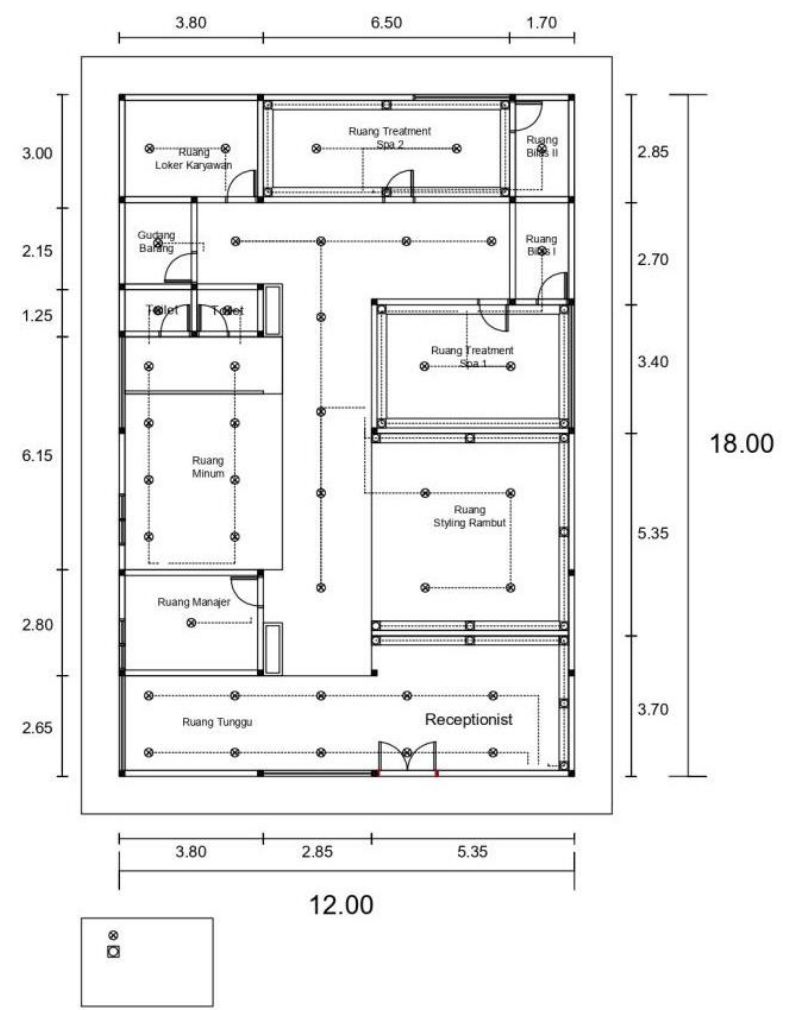

Gambar 13 Gambar Ceiling Plan untuk Perancangan Salon dan Spa Sumber : Dokumen Pribadi, 2021 


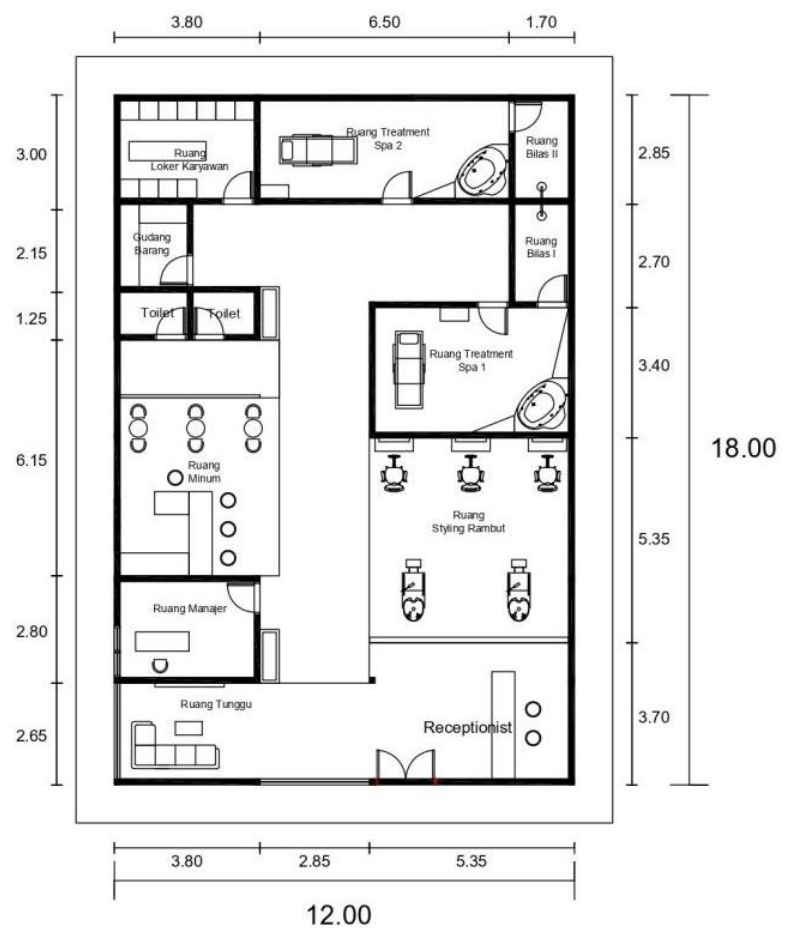

Gambar 14 Gambar Partition Plan untuk Perancangan Salon dan Spa Sumber : Dokumen Pribadi, 2021

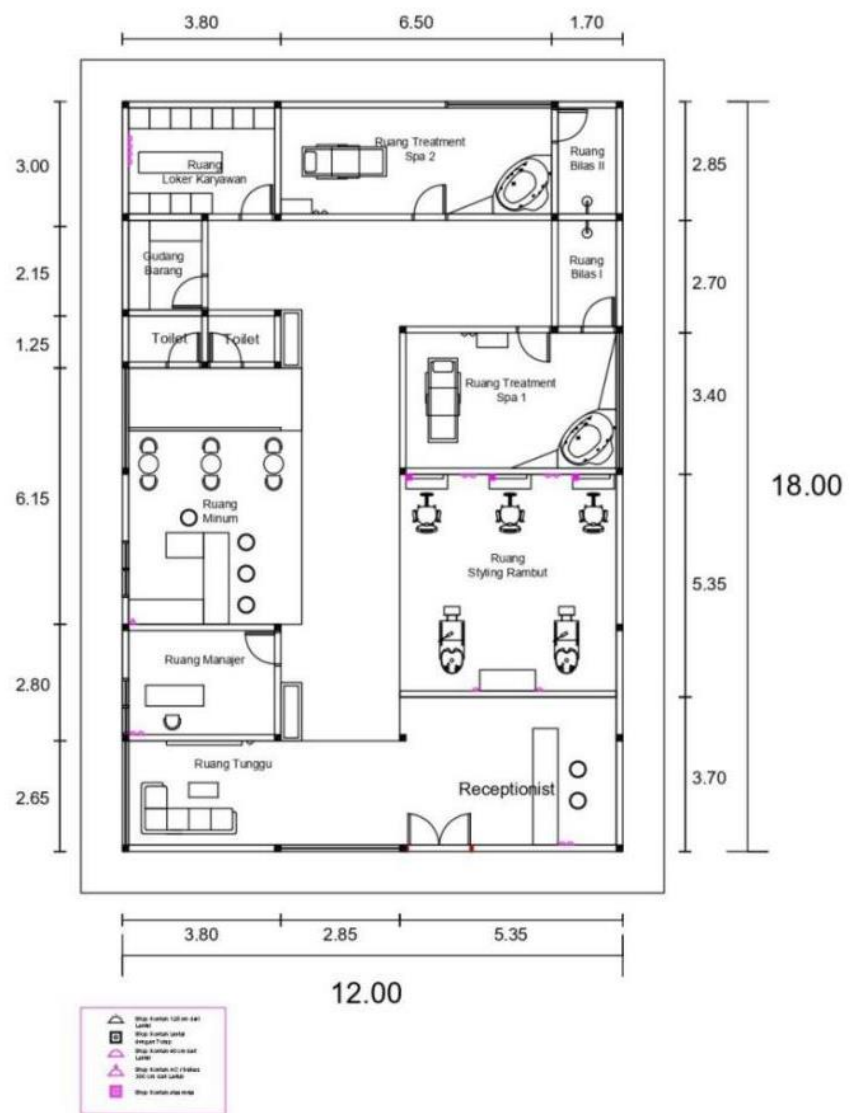

Gambar 15 Gambar M\&E Plan untuk Perancangan Salon dan Spa Sumber : Dokumen Pribadi, 2021 


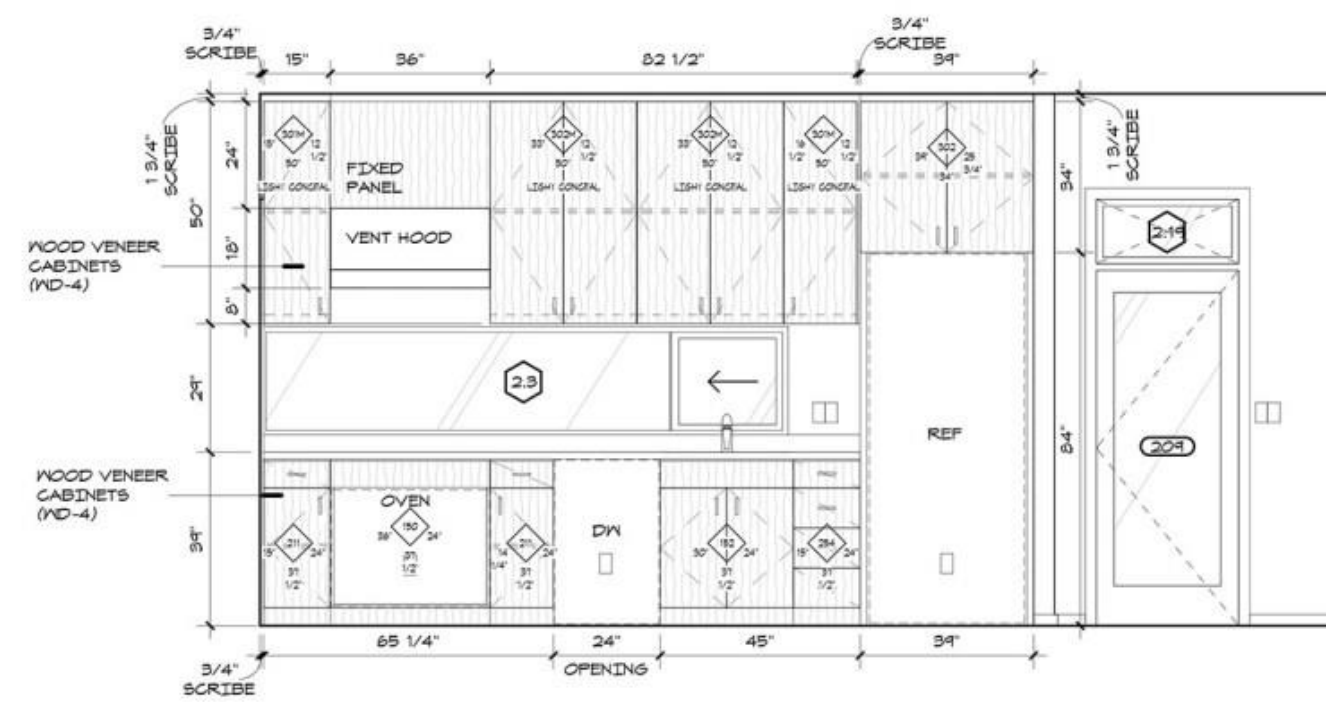

(11)

INTERIOR - KITCHEN \& UPPER PLAYROOM AREA

SCALE: $3 / 8^{\prime \prime}=10^{\prime \prime}$

Gambar 16 Illustrasi Gambar Kerja Detail Interior Sumber : (Kotak CAD 2021)

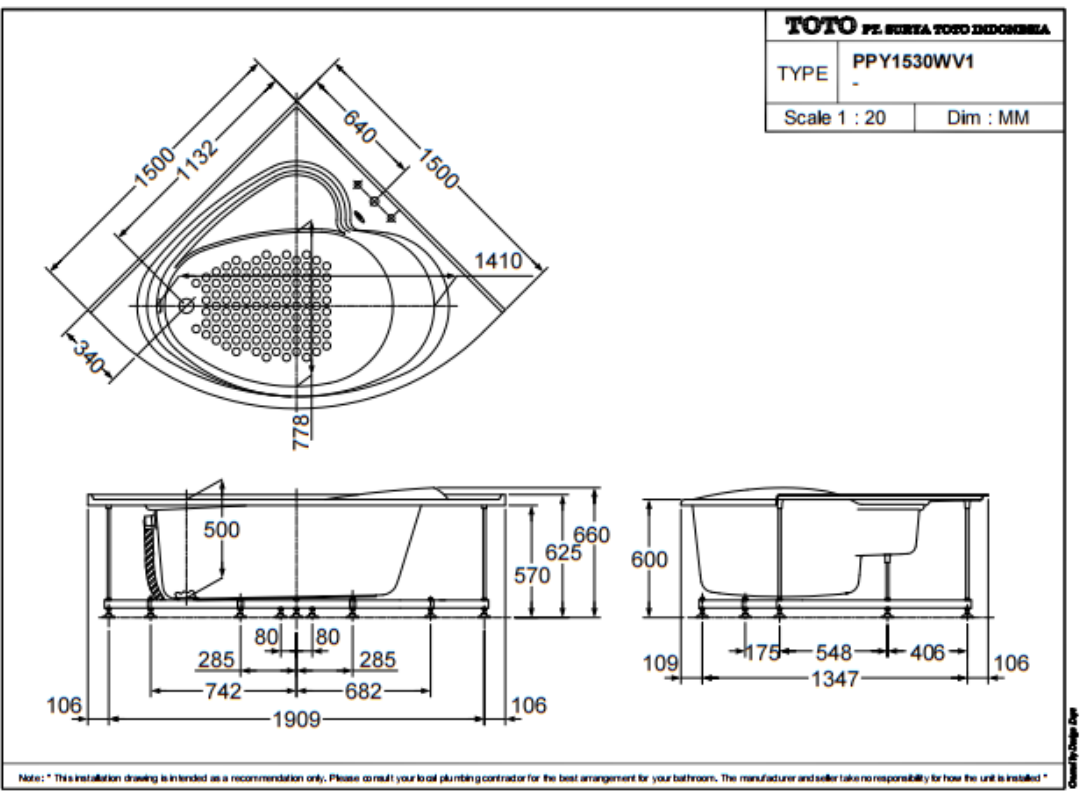

Gambar 17 Detail Furniture : Bathub pada ruang spa

Sumber : (TOTO Indonesia 2021) 


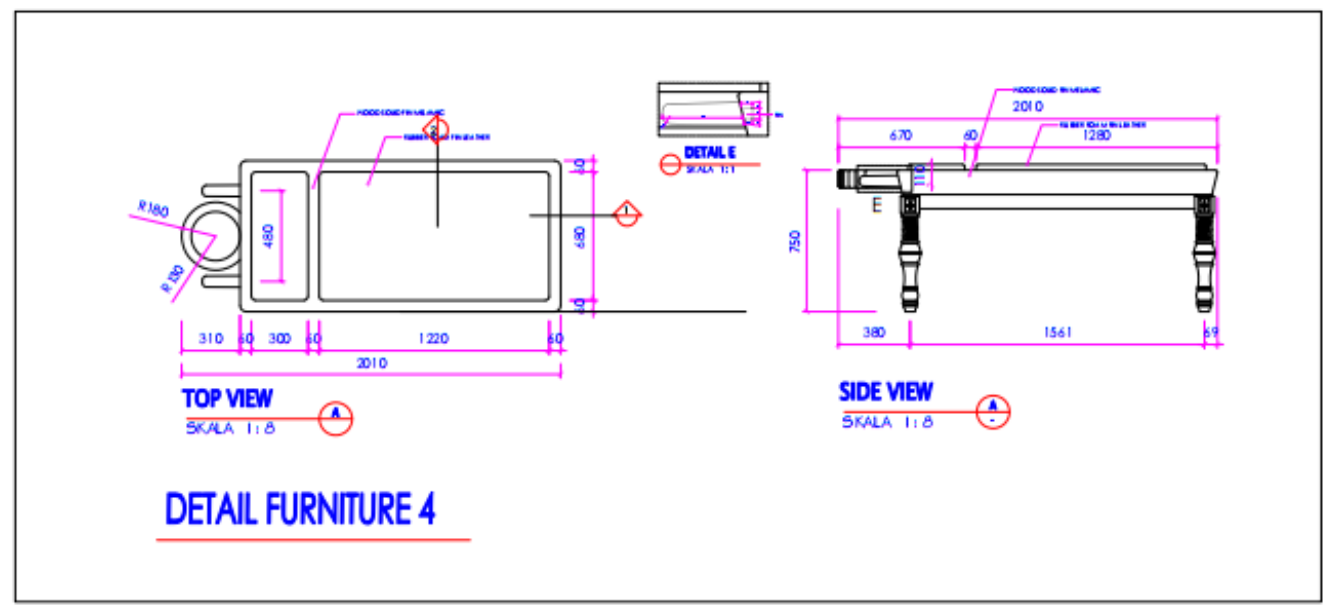

Gambar 18 Detail Furniture : Spa Bed Ruang Spa

Sumber : (Kotak CAD 2021)

\section{Mengerti Proses dan Tahapan Pengawasan Berkala}

1. Melakukan Pengawasan Berkala

Desainer interior mempunyai wewenang sebagai Pengawas, dalam perancangan salon dan spa ini antara lain adalah :

a. Mengetahui dan memberi persetujuan atas penilaian konsultan pengawas terhadap pekerjaan kontraktor, sehingga kontraktor mendapatkan haknya atas tahap pembayaran sesuai dengan prestasi yang telah dicapai.

b. Wewenang menolak hasil kerja Kontraktor terkait perancangan interior salon dan spa

c. Desainer Interior berhak menolak jika ada hasil pekerjaan yang ternyata tidak sesuai dengan desain interior salon dan spa yang sudah direncanakan di atas dan wajib memberikan solusi di lapangan melalui rapat koordinasi dengan konsultan pengawas.

2. Foto Dokumentasi Karya Jadi

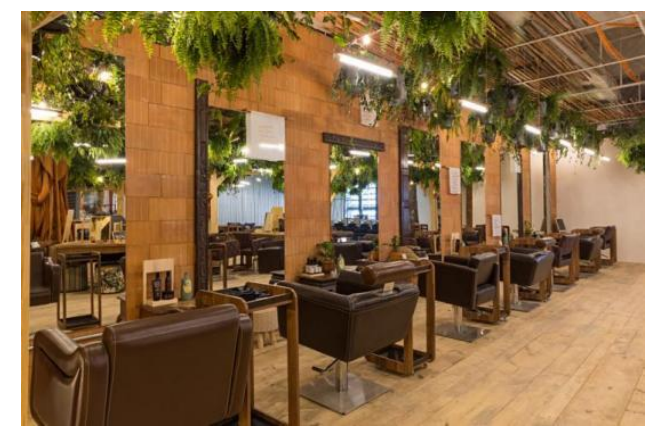

Gambar 19 Illustrasi Gambar Dokumentasi Ruang Salon Sumber : (Laces and Hair n.d.)

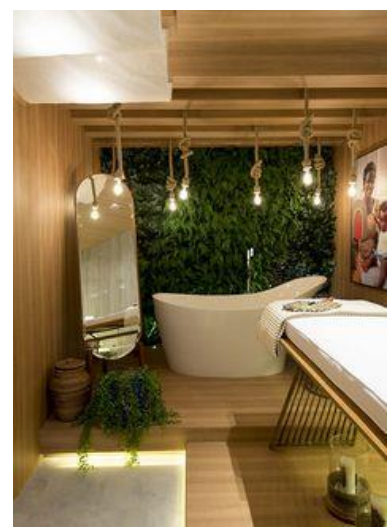

Gambar 20 Illustrasi Gambar Dokumentasi Ruang Spa Sumber : (Habitare 2018)

\section{Memahami Cara Membuat Laporan Pekerjaan}

1. Laporan Proses Desain

Laporan Proses Desain berisi informasi yang dilakukan selama proses desain hingga pelaksanaan hingga finalisasi implementasi desain interior pada ruang salon dan spa. 
2. Hukum, Kontrak dan Administrasi

a. Surat Refrensi

Surat refrensi atau surat keterangan kerja pada penelitian ini adalah surat refrensi yang diberikan oleh pembimbing kepada penulis untuk memberikan rekomendasi terhadap penulis untuk melakukan penelitian penyusunan dokumen serta perancangan interior salon dan spa ini.

b. Surat Perjanjian Kerja

Surat perjanjian kerja pada penelitian ini adalah surat perjanjian yang dilakukan antara pembimbing dan penulis untuk melakukan penelitian ini yang berisi ketentuan selama proses pembuatan penelitian.

\section{Simpulan}

Penyusunan dokumen desain perancangan interior Salon dan Spa ini bertujuan untuk memberi contoh gambaran tentang apa saja elemen - elemen yang dibutuhkan untuk dimasukkan ke dalam bentuk dokumen desain dalam perancangan desain interior, studi kasus dalam penelitian ini adalah salon dan spa.

Dalam penyusunan dokumen desain, ada tahapan perancangan (Pembuatan Konsep hingga pembuatan gambar kerja) dan tahapan pelaksanaan (Pembuatan RKS, RAB, Pengawasan hingga pembuatan laporan dan surat). Dalam penelitian ini, hanya difokuskan pada bagian perancangan, sementara bagian pelaksanaan hanya berupa penjelasan untuk mengilustrasikan proses. Tahapan - tahapan yang merupakan isi dari dokumen desain bagian perancangan yang tercantum adalah :

1. Mengetahui Sistem Manajemen Keselamatan, Kesehatan Kerja dan Lingkungan serta penerapannya dalam desain interior

2. Pemahaman Tahapan Studi Kelayakan Data, dengan mengumpulkan data untuk kebutuhan desain dengan teknik yang tepat serta tahapan proses menganalisis data yang telah didapatkan.

3. Tahapan Pra-Rancangan, data yang sebelumnya telah dianalisis dijadikan acuan untuk membuat solusi rancangan yang tepat dengan memasukkan konsep perancangan. Isi yang termasuk bagian dalam tahap Pra-Rancangan ini adalah membuat proposal desain dan 3D Perspektif Interior.

4. Membuat Rancangan, dalam tahapan ini ada dua poin utama yaitu pembuatan gambar kerja pendukung dan penjelasan spesifikasi penggunaan material dan warna pada desain. Beberapa yang termasuk dalam gambar kerja adalah Floorplan dan Layout Interior yang dapat menggambarkan susunan/rencana peletakkan furniture dan material lantai, sementara bagian spesifikasi berisi detail material/warna ruang dan furniture yang digunakan dalam desain interior.

\section{Ucapan Terima Kasih}

Penulis mengucapkan terima kasih kepada teman - teman penulis yang telah membantu dan mendukung dalam penyusunan penelitian ini. 


\section{Daftar Pustaka}

Aimee \& Co. Interior Styling. 2019. "Jungle Paradise." 2019. https://stylesourcebook.com.au/boards/jungle-paradise.

Azis, Abdul, and Teguh Dirgahayu. 2015. "Pengembangan Model E-Office Dan Purwarupa Intitusi Perguruan Tinggi Di Indonesia." JUITA ISSN : 2086-9398 3 (3): 130.

Balai Penerapan Teknologi Konstruksi. 2018. "Dokumen DED, RKS Dan RAB 2018." In MATERI SUPLEMEN PENGETAHUAN PEMBEKALAN KEPROFESIAN. Direktorat Jenderal Bina Konstruksi, Kementerian PUPR.

Ching, Francis D.K, and Corky Binggeli. 2012. Interior Design Illustrated Third Edition. Third. New Jersey: John Wiley \& Sons, Inc. https://doi.org/10.1038/nmat3445.

Create Wow. 2018. "Create Wow: Interieurstyling \& Ontwerp." 2018. http://www.makeithome.nl/wooninspiratie-woonideeen/jaren-70-interieur.html.

Cuendias, Belen. 2016. "Decorate Your Cabin, Design Your Style." 2016. https://www.academiestetic.com/decorar-centro-estetica/.

Habitare, Revista. 2018. "CASACOR Santa Catarina - Itapema 2018." 2018. https://www.revistahabitare.com.br/eventos/casacor-santa-catarina-itapema-2018/.

IFC, ADGI, ADPII, AIDIA, HDII, and HDMI. 2020. Dasar Pengadaan Dan Pengelolaan Jasa Desain Di Indonesia. Kedua. Jakarta Pusat: Kementrian Pariwisata dan Ekonomi Kreatif Deputi Bidang Kebijakan Strategis.

Jamaludin, Adon Nasrullah. 2015. Sosiologi Perkotaan. Edited by Tim Redaksi Pustaka Setia. Sosiologi Perkotaan. Vol. 2. Bandung: CV Pustaka Setia.

Juillet. 2018. "Services and Prices." La Déco d'Hélo. 2018. https://www.ladecodhelo.fr/prestations/.

KBBI Online. n.d. "Salon.” Accessed February 25, 2021. https://kbbi.web.id/salon.

Kotak CAD. 2021. “Gambar Detail Furniture V4.” 2021.

Laces and Hair. n.d. "No Title." Accessed March 15, 2021. https://www.lacesandhair.com.br/unidades-laces/note.

Legowo, Edy, and I.F Nurcahyo. 2018. Panduan Pendirian Usaha Studio Desain Interior. Vol. . Jakarta: Badan Ekonomi Kreatif.

Nugraha, Krisna Tri. 2017. "PERANCANGAN INTERIOR INDOBIK SEBAGAI PUSAT INKUBATOR BISNIS KREATIF DI SURAKARTA." Institut Seni Indonesia.

Nur Z, M.Mahirudin. 2010. "Studi Kualitas Dokumen Desain Dan Faktor-Faktor Yang Mempengaruhinya Menurut Konsultan Perencana Pada Proyek Konstruksi Di Surakarta." Universitas Sebelas Maret.

Pebrina, Eci, Hayatunnufus, and Merina Yanita. 2016. "STUDI TENTANG SARANA DAN PRASARANA SALON KECANTIKAN DI KOTA SUNGAI PENUH." E-Journal Home Economic and Tourism 13 (3): 1.

Pendidikan Pusat Pelatihan Sumber Daya dan Air. 2017. Modul Pemahaman Sistem Manajemen Keselamatan Dan Kesehatan Kerja Konstruksi ( SMK3K). Bandung: Badan Pengembangan Sumber Daya Manusia, Kementerian PUPR. 
Peraturan Direktur Jenderal Bina Gizi Kesehatan Ibu dan Anak. 2011. Pedoman Penyelenggaraan Salon Kecantikan di Bidang Kesehatan. 01.01/BI.4/4051/2011, issued 2011. https://123dok.com/document/dy4655rz-peraturan-direktur-kesehatan-tentangpedoman-penyelenggaraan-kecantikan-kesehatan.html.

Peraturan Menteri Kesehatan RI. 2014. Pelayanan Kesehatan SPA. Nomor 8, issued 2014.

Peraturan Menteri Pariwisata. 2019. Standar Usaha SPA. 11, issued 2019.

Prabasari, Putu Khatalia, Sriti Mayang Sari, Celline Junica P, Program Studi, Desain Interior, Universitas Kristen Petra, and Jl Siwalankerto. 2018. "Perancangan Interior Beauty Lounge Salon Di Bali" 6 (2): 210-18.

Prianto, Eddy. 2020. "Pengusulan SKA Muda, Projek 03 Virtual : Shopping Mall Respond Covid19."

Sari, Milya, and Asmendri. 2020. "Penelitian Kepustakaan (Library Research) Dalam Penelitian Pendidikan IPA." Natural Science $6 \quad 43$. https://ejournal.uinib.ac.id/jurnal/index.php/naturalscience/article/view/1555/1159.

Setiawan, Sherly, Sriti Mayangsari, Priyo Suprobo, Program Studi, Desain Interior, Universitas Kristen Petra, and Jl Siwalankerto. 2016. "Perancangan Interior Woman Health and Beauty Di Surabaya" 4 (2): 483-92. https://media.neliti.com/media/publications/92125ID-perancangan-interior-woman-health-and-be.pdf.

Spencer, Laura. 2020. "Top 20 Template Desain Grafis (Branding) Penawaran Proyek." 2020. https://business.tutsplus.com/id/articles/graphic-design-branding-project-proposaltemplates--cms-30556.

Sudirman, Dede. 2020. "Apa Itu Virtual? Pengertian, Contoh Dan Fungsinya." 2020. https://virtualiable.com/apa-itu-virtual-pengertian-contoh-dan-fungsinya/.

TOTO Indonesia. 2021. “PPY1530WV1.” 2021. https://www.toto.co.id/products/PPY1530WV1.

Velde, Van De. n.d. "Monreale Armchair." Accessed March 15, 2021. https://www.vdv.com.br/public/produto/poltrona-monreale. 